\title{
The Verbs with the Notion of Eating in Manggaraian Language: Natural Semantic Metalanguage Analysis
}

\author{
Tobias Gunas ${ }^{1}$, Sebastianus Menggo ${ }^{2}$, Yosefina Helenora Jem $^{3}$ \\ ${ }^{123}$ Universitas Katolik Indonesia Santu Paulus Ruteng \\ gunastob07@gmail.com
}

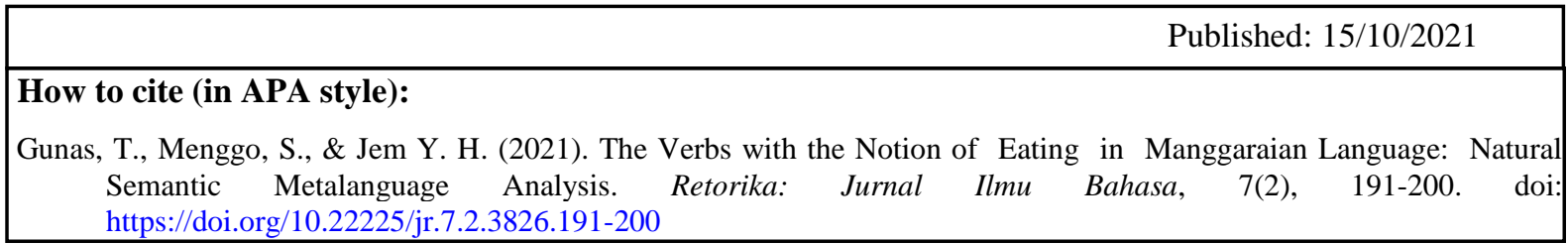

\begin{abstract}
The aim of the research is to explicate and account for the verb of eating in Manggaraian language. There are some verbs denoting the meaning of eating, such as hang, lompong, jumik, mboros, takung, la'ur, alas, pongo mu'u. The qualitative research method was applied to unveil and explain the explication of meaning in the given verbs respectively. Field-observation and recording were the techniques used to gather the data from the natural speakers utterances as well as part of the data were based on the researchers' intuitive knowledge as the native speakers. The data were analyzed through the theory of Natural Semantic Metalanguage (NSM). The results of the analysis reveal that Manggaraian language has the inventory of verbs designating the meaning of eating such as hang, jumik, lompong, mboros, takung, raci, alas, pongo mu'u. In terms of semantic prime, the verbs are under the category of the action verb. Comparing to the other verbs, the verbs jumik, lompong, pongo $m u^{\prime} u$ have more delicate meaning of eating. Furthermore, those verbs are classified into generic and specific category of meaning. The verbs "hang, jumik, mboros" are generic in meaning while the verbs lompong alas,racik, pongo mu'u, takung are specific in meaning. The verbs are categorized into non-compositional polysemy. Regarding the explication of meaning, the verbs reveal the action and the process of eating involving certain parts of body (hands and mouth) as well as specific tools (plate, spoon, bowl).
\end{abstract}

Keywords: Manggaraian language, Natural semantic metalanguage, Verb

\section{INTRODUCTION}

Any language in the world are useful and significant when they convey meaning to speakers or participants in interaction. Hence, it is true that meaning is a part or component of language system. By its nature, language is defined as a system of arbitrary vocal symbols and a system of meaning. In a system of arbitrary vocal symbols, language produces various speech sounds as the combination of consonants and vowels which signifies meaning, whereas a system of meaning means that language has the property of sense and ideational concepts which is cognitively constructed and then realized in speech sounds, words, sentences as well as discourse. Shortly, any human language is generally constructed of form and meaning (Fromkin, Rodman \& Hyams, 2011).

Concerning form and meaning, human language has a rich repertoire of words expressing a variety of meanings. Through a variety of word meanings, speakers could produce utterances conveying particular functions, such as defining, representing, manipulating, directive, emotive function as well as describing and explaining their state of being and activities in life (Menggo, Suastra, 
Budiarsa, \& Padmadewi,2019). Therefore, knowing meaning is vitally important for people to negotiate with others in daily communication. Moreover, it is meaning that speakers and hearers in communication attempt to understand each other. As Kempson (1977) in (Mulyadi \& Siregar, 2006) starkly emphasized that meaning is necessarily required by the speaker in communication. Meaningful communication reflects the language attitudes and communication strategies of the interlocutors in real interaction (Menggo \& Suastra, 2020). Therefore, a speaker is encouraged to consider what the word means before saying it.

In utterance, each word deployed has both lexical meaning and contextual meaning. Recognizing the lexical meaning of a word can be used as a hint for drawing a contextual meaning. For instance, the word "rose" has a couple of meanings; it is a sweet-smelling flower with thorns, pink color or a piece of metal with small holes attached to a pipe for watering plants. One of these meanings may be applied as the basic referent relating to the word "rose" in context. However, grasping word meaning is not as simple as merely picking up a single meaning among some other meanings. In fact, words may have a set of meaning which are not simple to get across. Those words have a single meaning as seen on surface structure, while there could be more related meanings as analyzed in deep structure. In this case, identifying a word meaning is more complicated when it denotes multiple meanings.

Word is a combination of syllables consisting of consonants and vowels (Sari et al., 2021). The word meaning is related to lexical categories. According to Fromkin, Rodman \& Hyams (2011), "lexical categories typically have particular kinds of meanings associated with them. Those lexical categories include verbs usually referring to actions, events, and states; adjectives to qualities or properties; common nouns to general entities; and proper nouns to particular individuals". In case of a causative verb which shows the action that causes something to happen or someone to do an activity, there are some related words "make, get, force, cause, have" (Griffths, 2006).

Word with multiple meanings is concerned with the case of polysemy and ambiguity. Polysemy occurs to a word having a set of meanings. As Allan (1986) maintains that, "polysemy is the property of an emic expression with more than one meaning". To illustrate the case, the English word bachelor is taken as an instance of word with multiple meanings. The word means an unmarried man of any age, a person who has taken the first or the lowest degree at university, and a young feudal knight who followed the banner of another. In the case of polysemy, it seems more complicated to deal with multiple meanings in a word. Therefore, it requires an approach to recognize a set of meanings included in a word. Recognition of word meaning is very useful for speakers in any language for communication.

Pertaining to word meaning analysis, there is a general semantic concept which has been widely recognised as semantic universal. Semantic universal has a system of semantic prime which can be applied for semantic analysis in any language. Semantic prime is the core part of Natural Semantic Metalanguage (NSM) which is required for decomposing word meaning into semantic molecules. Moreover, NSM provides the explication of word meaning for well-specified grammar (Gladkova et al., 2016).

Every language has a remarkably unique system of word meaning. It is notably seen in the case of action verbs and process verb. As in other languages, Manggaraian language, a local language spoken by people in west Flores, builds its system of word meaning which is applied to daily communication. In the verb of eating, Manggaraian language has some verbs in such lexicons as hang, lompong, jumik, mboros, takung, raci, alas, pongo mu'u.".

This study mainly aims to describe and explain the verbs with the notion of eating in Manggaraian Language. Natural Semantic Metalanguage approach is employed to explore the semantic prime and explication of the verb. The verb "hang" is considered as the focus of this analysis since it is the basic meaning of the verbs "lompong, jumik, mboros, la'ur pongo mu'u, takung, racik, alas". These words are used for different meaning and in a diversed context of communication. Therefore, this semantic analysis which is based on NSM approach is particularly concerned with the action verb "hang" (eating) categorized as to do something or something happen in the semantic primes. The above explanation enables the researcher to propose two questions in this study, namely (1) what are the types of the verb 
'to eat' in the Mangarai language, and (2) what are the differences in the use of the verbs 'to eat' in the Mangarai language.

The complexity of word meaning in language has drawn researchers' attention and interest to carry out various studies on analysing word meaning through Natural Semantic Metalanguage. Those studies investigated semantic analysis in different languages; two researches analysed word meaning in local languages in Indonesia, and the other investigations looked at word meaning in English language. In particular, the studies contribute to the development of the present semantic analysis in Manggaraian language in terms of theory and method of analysis from Natural Semantic Metalanguage.

Sarwadi (2016) analyzed semantic meaning of predicate Mangan in Sasak Language. This analysis employes Natural Semantic Metalanguage approach. The study was designed in a qualitative research method. The study found that there are some lexicons related to the verb Mangan, namely Ngajengan, Daharan, Ngelor, Mangan, Ngrodok (Eating), Kaken (Eating), Suap, Bejijit, (Eating) Bekeruak (Eating), Ngerasak (Eating) and Nyangklok (Eating). The lexical meaning of Ngajengan, Daharan, Ngelor, Mangan, Ngrodok (Eating), Kaken (Eating), Suap, Bejijit, (Eating) Bekeruak (Eating), Ngerasak (Eating) and Nyangklok (Eating) was doing something to eat but the differences of these words are used in sentences. Besides, the word usage is based on the subject and object and there is a predicate that needs a tool to state to eat meals or food.

Further, the other research was conducted by (Setiawan, Beratha \& Sukarini, 2019) which studied the semantic analysis on the verb "pick up" subtype do/happen. This research applies the Natural Semantic Metalanguage approach in analyzing the idiomatic meaning of the phrasal verb. The results of the study indicate that Natural Semantic Metalanguage contributes significantly to avoid misunderstanding of the phrasal verb "pick up" that has eight meanings, and the phrasal verb is categorized as non-composition polysemy between do/happen.

Further, Gladkova et al ( 2016) conducted a pilot experimental study that aimed at evaluating natural semantic metalanguage (NSM) explications of English interjections. It proposes a novel online survey technique to test
NSM explications with language speakers. The survey tested recently developed semantic explications of selected English interjections as found in Goddard (2014a): wow, gosh, gee, yikes ("surprise" group) and yuck, ugh ("disgust" group). The results provide overall support for the proposed explications and indicate directions for their further development. Interestingly, respondents' preexisting knowledge of NSM and other background variables (age, gender, being a native speaker, or studying linguistics) were shown to have little influence on the test results.

The previous studies mentioned above have shown the explication of meaning in verbs based on natural semantic metalanguage theory. In line with the explication of the verb eating in Manggaraian language, natural semantic metalanguage is also applied in this investigation. By applying the NSM approach, this research reveals the semantic structure of the verb of eating in Manggaraian language. Additionally, the results of the semantic analysis can discern the confusion and misunderstanding of the verb in communication.

In conjunction with semantic analysis, Natural Semantic Metalanguage has been widely applied in describing and explaining word meaning in all languages. Natural Semantic Metalanguage (NSM) deals with a decompositional system of meaning representation based on empirically established universal semantic primes, i.e., simple indefinable meanings that appear to be present as word meanings in all languages. Natural Semantic Metalanguage approach employs the theoretical construct covering up semantic primes, namely allolexy, syntactic frames and valency options of primes, semantic templates, semantic molecules, semantic prototypes for grammatical constructs, grammatical polysemy, ethnosyntax, and cultural scripts (Goddard, 2012).

Wierzbicka (1992) posited that semantic prime decomposes word meaning into components that cannot be segmented into any smaller parts. Semantic primes are applied to lexical universals. Every semantic prime has its grammar of relationships involving the other primes with which it can be combined. NSM currently employs 65 semantic primes; for instance, substantives, determiners, speech, time, and space, with equivalents in most 
languages (Cavanagh et al., 2019). Therefore, its universality can be employed to analyze word meaning in other languages, including the verb "hang" in local Manggaraian language. The following is the semantic prime proposed by Wierzbicka.

Table 1. Semantic Prime

\begin{tabular}{|c|c|}
\hline Category & Primes \\
\hline Substantive & $\begin{array}{l}\text { I, you, someone, } \\
\text { people, } \\
\text { something/thing, } \\
\text { body }\end{array}$ \\
\hline Relational substantive & Kind, part \\
\hline Determiners & $\begin{array}{l}\text { This, the same, } \\
\text { other else another }\end{array}$ \\
\hline Quantifiers & $\begin{array}{l}\text { One, two, some, all, } \\
\text { much/many, little/few }\end{array}$ \\
\hline Evaluators & Good, bad \\
\hline Descriptors & Big, small \\
\hline Mental Predicates & $\begin{array}{l}\text { Think, know, want, } \\
\text { don't want, feel, see, } \\
\text { hear }\end{array}$ \\
\hline Speech & Say, words, true \\
\hline Actions, events, movements & Do, Happen, Move \\
\hline Existence and possession & $\begin{array}{l}\text { Be (somewhere), } \\
\text { there is, be } \\
\text { (someone/something), } \\
\text { (is) mine }\end{array}$ \\
\hline Life and death & Live, die \\
\hline Time & $\begin{array}{l}\text { When/time, now, } \\
\text { before, after, a long } \\
\text { time, a short time, for } \\
\text { some time, moment }\end{array}$ \\
\hline Space & $\begin{array}{l}\text { Where/place, here, } \\
\text { above, below, far, } \\
\text { near, side, inside, } \\
\text { touch (contact) }\end{array}$ \\
\hline Logical concepts & $\begin{array}{l}\text { Not, maybe, can, } \\
\text { because, if }\end{array}$ \\
\hline Intensifier, augmentor & Very, more \\
\hline Similarity & Like/as/way \\
\hline
\end{tabular}

The semantic prime is employed to decode the meaning of words in all languages in the world. In the semantic prime, there is a category of sixteen parts generally found in any language. Therefore, it has been widely applied to analyse the meaning of words in different languages, including Manggaraian language as a local tongue.

Manggaraian language as a local language typically has the inventory of lexicons denoting the activity of eating. Those lexicons are "hang, lompong, jumik, takung, mboros. They have the same basic meaning. Nevertheless, the lexicons are not simple to be captured by speakers from other language backgrounds and even for younger Manggaraian native speakers in communication. By this semantic analysis of Natural Semantic Metalanguage, it is expected to provide the explication of the word meaning for those words respectively.

\section{METHOD}

A descriptive qualitative research is applied to describe and explain the semantic explication of action verbs eating in Manggaraian language. The data for this study are naturally verbal data from the Manggaraian speakers'utterances. Field observation, recording and interview are the techniques 
employed to obtain the data from the field. The data were also collected based on the researchers'intuitive knowledge as the native speaker of Manggaraian language. The data analysis was conducted through some procedures, namely: data reduction (identification and classification), data display, and data interpretation. Further, the data were interpreted from Natural Semantic Metalanguage (NSM) approach.

\section{RESULTS AND DISCUSSION}

Manggaraian language employs a number of lexicons indicating the meaning of eating.
The lexicons are categorized into action verb. Among the verbs of eating, the word "hang" is most generally spoken by the Manggaraian speakers addressing the activity of eating something (food or meals). The verb "hang" has the prime meaning of eating. Additionally, the verb "hang" has some subtypes of the verbs of which their meaning is eating such as in the words "lompong, jumik, alas, pongo mu'u, mboros, takung". The data presented in table 1 below displays the form, meaning, and function of the verb "hang" with some subtypes designating the action verb of eating.

Table 1. The Verbs of Eating in Manggaraian Language
\begin{tabular}{|l|l|l|l|l|}
\hline Lexicon & Process & $\begin{array}{l}\text { Parts } \\
\text { of } \\
\text { Body }\end{array}$ & Tools & $\begin{array}{l}\text { Mean } \\
\text { ing }\end{array}$ \\
\hline Hang & $\begin{array}{l}\text { Taking } \\
\text { food by } \\
\text { hands into } \\
\text { the mouth } \\
\text { and } \\
\text { chewing it }\end{array}$ & $\begin{array}{l}\text { Hands } \\
\text { Mouth }\end{array}$ & $\begin{array}{l}\text { Plate } \\
\text { hands } \\
\text { and } \\
\text { spoon }\end{array}$ & $\begin{array}{l}\text { To } \\
\text { eat } \\
\text { food } \\
\text { or } \\
\text { other } \\
\text { meals }\end{array}$ \\
\hline $\begin{array}{l}\text { Lompong } \\
\text { Jumik } \\
\text { Mboros } \\
\text { Alas } \\
\text { Raci } \\
\text { Pongo } \\
\text { mu'u } \\
\text { food by } \\
\text { hands into } \\
\text { the mouth } \\
\text { and } \\
\text { chewing it } \\
\text { Taking } \\
\text { food by } \\
\text { hands into } \\
\text { the mouth } \\
\text { (focus) } \\
\text { Serving } \\
\text { food to } \\
\text { someone, } \\
\text { particularil } \\
\text { y baby, the } \\
\text { sick or the } \\
\text { elderly }\end{array}$ & & & $\begin{array}{l}\text { Houth } \\
\text { Bowl }\end{array}$ & $\begin{array}{l}\text { To } \\
\text { eat } \\
\text { fpoon } \\
\text { hands } \\
\text { or } \\
\text { other } \\
\text { meals }\end{array}$ \\
Takung & & & $\begin{array}{l}\text { To } \\
\text { eat } \\
\text { food } \\
\text { or } \\
\text { other } \\
\text { meals } \\
\text { by } \\
\text { the } \\
\text { help } \\
\text { of } \\
\text { others }\end{array}$ \\
\hline
\end{tabular}

With respect to the lexicons presented in table 1 above, it turns out that the verb "hang" has the basic meaning of eating, that is to eat food or other meals. The basic meaning is also applied to the other related lexicons such as Lompong, Jumik, Mboros Alas, Racik, Pongo mu'u, takung. In this case, the verb "hang" is categorized as the non-compositional polysemy. Based on semantic prime, the given lexicons are under the category of action verb.

The verb "hang" to eat food or meals

In Manggaraian language, the verb stressing the notion eating has unique features, namely: generic and specific meaning. The generic meaning of the verb eating is conveyed by the verb "Hang" with its subtypes "jumik, mboros". The specific meaning is found in such verbs as "pongo mu'u, lompong, takung, alas, racik". Semantically, to know and understand the verbs, it is necessary to explicate the meaning of the verbs through Natural Semantic Metalanguage analysis.

The verb "hang" is the action verb designating the notion of eating. It is generally used by the Manggaraian speakers when eating 
some food, snacks, or meals. The action of eating involves a process of taking some food or meals by hands and of chewing them into the mouth. Likewise, the same process of eating is reflected in the verbs "jumik, mboros, lompong, takung, pongo mu'u, alas, racik". Comparing to the other verbs of eating, the verb is considered having more neutral sense for various subjects from different ages, sexes, social status, and another social stratification in any context of communication is used in nonhuman subjects and abstract nouns. When the use of the verb "hang" is neutral to all speakers, the family atmosphere is very prominent.Speakers feel relaxed, however at the same time highlighting the significance of words in a proper sociocultural sense when communicating (Menggo, 2017). The use of the verb "hang" is seen in the extract below:

\section{Extract (1):}
a. Sanggen weki beo hang woja weru one takung penti.
b. Mai ga anak koe, hang tété so wa.
c. Poli taung hang ase kae dite bo ga?
d. Becur, ho koe di poli hang leso.
e. Ami poli hang ga.

As shown in the data of the extract 1 , the verb "hang" clearly denotes the prime meaning of eating. The meaning describes the process of eating food such as woja weru (new rice) and tete (potatos). This edible food is taken into the mouth by using hands and spoons as the tools. The subjects involved in the eating activity are different subjects, namely sanggen weki (all people, anak koe (children), ase kae dite (our brothers) and followed by the food as the object. In terms of construction, it is clear that the verb" hang" can be applied to any human subjects and concord with any food in context. In another construction, however, the verb" hang" takes no direct object as in the cases (d) and (e). The object can be understood from the context. Within such a construction, the meaning of the verb is not changed.

\section{The explication of the verb "hang"}

The meaning of the verb is explicated as follows

- $\mathrm{X}$ does something to $\mathrm{Y}$

- This happens for some time

- Because of this, something happen to Y

- Because of this, something happen to Y
- Because of this, people need to do something

- $\mathrm{X}$ does something like this.

From the explication, it can be seen that the verb" hang" means the activity of eating food or meals served in the mouth by using hands and a spoon. In this case, someone (any subject) is taking food or meals into the mouth by hands and a spoon. There is no difference for human subjects in doing such an activity. Besides, this meaning illustrates a literal sense as well as a positive mood of the verb used in that context.

By contrast, the verb "hang" does not mean occur in a single context where it just provides a basic meaning. In another context of use, its meaning has been extended to a metaphorical meaning. The metaphorical meaning of the verb is associated with bad things in real-life situations. Below is the case in point.

Extract (2):

1) Kraeng Kepala Desa hang seng de roeng.

2) Eme toe pande lemeu acara hitu, empo demeu ngance hang sanggen taungs weki one beo demeu.

In the extract, the verb "hang" has a set of metaphorical meanings different from its literal meaning. In these two cases, the verb "hang" (in 2.a) connotes abuse of money illegally for one's interest or corrupt some money, while in 2.b the verb connotes kill. This metaphorical meaning states something other than the literal meaning or ordinary meaning of the word (Jama et al., 2020; Jensen, 2006; Wearing, 2009). With regard to this metaphorical meaning, it can be explicated as follows.

\section{The Explication of the verb "hang" to corrupt}

The meaning is explicated below:

- $\mathrm{X}$ does something to $\mathrm{Y}$

- This happens for some time

- Because of this, something happen to Y

- Because of this, something happen to Y

- Because of this, $X$ wants to do something

- X does something like this.

In this explication of metaphorical meaning, the verb "hang" connotes "corrupt" money. This meaning occurs due to the association of the verb to object "seng". The word "seng" (money) means coins or paper notes used for buying or paying something; 
thus, it is something to be inedible. There is a change of meaning to the verb "hang", depending on what words it collocates with. Moreover, inedible objects can be collocated with the verb "hang".

\section{The Explication of the verb "hang" kill}

In contrast to the above metaphorical meaning, the verb "hang" connotatively means "kill". This meaning has a negative sense. The explication can be presented below:

- $\mathrm{X}$ does something to $\mathrm{Y}$

- This happens for some time

- Because of this, something happen to Y

- Because of this, $X$ uses invisible power

- Because of this, X wants to do something (kill)

- X does something like this.

Based on the explication of meaning, it points out that the verb "hang" has metaphorically extended its meaning. In this case, this metaphorical meaning comes out from the collocation of the verb "hang" and the animate object "sanggen taungs weki" as the offering. The metaphorical meaning of kill is not physically done by a human's hand, but it is invisibly made through the power of the ancestor's spirit. In addition to that, it is found that an abstract noun can be the subject of the verb "hang".

\section{The Subtypes of the Verb " hang"}

The verb "hang" has some subtypes of words closely related in meaning. Those words are referring to the activity of eating. The verbs are "lompong,jumik, alas, pongo mu'u". However, the verbs explicate different meanings respectively. The verb "lompong" addresses a meaning that people use a bowl to eat some meals. The verb" jumik" stresses a meaning of eating some food with a modern eating ware like spoon and plate. The verb"alas" means eating for breakfast. Further, the verb "pongo mu'u" denotes the meaning of eating some food or meals with mouth. The following data are presented to show the use of the verbs in utterances :

\section{Extract (3):}

1) Asa mori, mai lompong leso taung ga.

2) Asa kraeng, jumik cama cé mbaru tong wi'é.
3) Isé tuang guru rémé pongo mu'u dé.

Regarding the existing data in extract (3), the verbs "lompong/jumik/alas/pongo mu'u" denote the literal meanintg of eating. However, when they are put into the context of use, they show a more polite meaning. In this case, the honorific terms such as "mori, kraeng, ema, and tuang guru" are the subjects applied to those verbs addressing politeness to the older, respected persons, and distinguished social status. The meaning of the verb "lompong" can be explicated below:

\section{The Verb"Lompong" to eat food or meals}

The word "lompong" basically refers to the bowl used by people to put some rice. It is changed into the verb indicating the action of eating some food or meals with the bowl as the instrument. Consider the instances below:

a. Meka awo mai Mano reme lompong wie.

b. Hi ema tua reme lompong leso.

c. Ise amang lompong sina mbaru tong wie.

Based on the data, the verb "lompong" which means eating addresses more on the use of the bowl as the tool. Therefore, it is more specific than the other verbs in meaning.

\section{The Explication of the Verb "Lompong"}

- X does something to $\mathrm{Y}$

- This happens for some time

- Y can be older people or distinguished social status (mori, kraeng, ema)

- Because of this, Y gets more respected and feels more convenient.

- Because of this, X wants to state something (lompong)

- X does something like this.

From this explication, it can be clearly seen that the verb "lompong/jumik/alas/pongo mu'u" has a more polite meaning than the word "hang". It is commonly used to express the meaning of eating to adults, older people, or a guest. The utterance of these words confirms that the Manggarai people honor the etiquette and other values of life.

The Verb "mboros" means to eat food or meals

The verb "mboros" has the meaning of eating. It refers to the activity of consuming food or meals in the mouth by hands and a spoon. For 
its rude sense, it is not generally spoken by people in a normal situation and context. However, people commonly use it to express a bad mood to others, for instance in a situation of anger or feeling of dissatisfaction toward one's behavior. Furthermore, these two terms are used to identify child speaker familiarity. The following instances illustrate the use of the verb "mboros".

Extract (4) :

1) Anak koe hitu mboros taung hang eta meja.

2) Anak koe, mai mboros ga.

3) Mai kaut mboros ata so ew.

4) Toe mboros hau ko.

The data reveal that the verb "mboros" means eating food or meals in the mouth by hands and spoon. Particularily, such verb carries three meanings, namely (1) and (3) eating up and eating greedily, (2) and (4) eating intimately.

\section{The Explication of the Verb "mboros"}

The meaning of the verb "mboros" can be presented in the following explication.

- X does something to $\mathrm{Y}$

- This happens for some time

- Y can be adults or children (ata, anak koe)

- Because of this, Y gets unrespected and feels inconvenient.

- Because of this, X wants to state something in a bad mood (mboros)

- X does something like this.

Given the explication, the subject who employs the verb "mboros" is someone who is feeling in a bad mood to others in a particular context. For instance, someone who is angry with his children or kids. The word encapsulates the idea of anger. the verb "mboros" sounds a stronger negative sense. Besides, it explicates the pejorative meaning, that is to look down on others. Therefore, it is advisable to avoid using the verb in that sense.

\section{The Verb "takung" to eat food or meal}

The verb "takung " means the activity of eating food or meals by hands and spoon with the help of others. This eating process is not done for the subjects'own sake, but mostly for those in need of others'assisstance. This verb is particularly used when someone helps the baby, the sick, and the elderly people to eating food or meals. Consider the following instances in extract (5) below:

Extract (5):

1) Leni takung bubur latang mantar koe'n (baby).

2) Nadus takung hang latang ema tua'n (grandfather/the elderly).

3) Fridus takung bubur latang te ende'n ata beti (the sick).

Similarly, the verb "takung" deals with the activity of eating food. Yet, the person to whom some food or meals is served is specifically those who are disable to do eating for themselves. The verb reflects the meaning of eating with the help of other people. In this case, someone gives a help to them to eat some food or meals.

\section{The Explication of the Verb "takung"}

The meaning of the verb " takung" can be explicated as follows:

- X does something to $\mathrm{Y}$

- This happens for some time

- Y can be a baby, the sick or the elderly (mantar koe, ema tua, ende ata beti)

- Because of this, Y feels happy and convenient.

- Because of this, $X$ wants to do something (takung) to $\mathrm{Y}$

- X does something like this.

The explication of the verb "takung" expresses a more delicate sense than other words having the basic meaning of eating. It provides the meaning of helping others to eat. In particular, the verb means helping to eat for those with the inability of doing the action by themselves. This verb cannot be used to adults who can eat some food or meals. The abovementioned data strengthen the concept of metalanguage approach, which emphasizes that metalanguage provides speakers the ability to create new meanings as long as listeners recognize and accept those meanings in the interaction (Allan, 2016). This notion is line with the Theory of Natural Semantic Metalanguage (NSM), which highlight on system of meaning representation based on empirically established universal semantic primes (Goddard, 2012; Nasution \& Mulyadi, 2020; Rannas \& Rosa, 2020).

The verb "pongo mu'u" to eat food or meal 
The verb "pongo mu'u" is basically similar to the verb "hang" in meaning. This verb shows a process of eating food or meals taken into the mouth. It emphasizes specifically on the words "pongo" (tie) and "mu'u" (mouth). The verb means the action of eating and chewing some food or meals happening in the mouth. It does not matter what tools or instruments are used by a person. As to compare with the other verbs of eating, the verb "pongo mu'u" is more delicate in meaning.

\section{The explication of the meaning}

The meaning of the verb "pongo mu'u" can be explicated as follows:

- X does something to $\mathrm{Y}$

- This happens in the mouth

- Y can be food or meals

- Because of this, $X$ eats and chews food or meals in the mouth.

- X does something like this.

The explication of meaning above points out that the verb "pongo mu'u" is specifically related to the activity of eating in the mouth as the part of the body. In context, such verb is used when participants are older in age or having the higher social status. Moreover, the verb is employed to show respect to those people attending a special ceremony.

\section{The verbs "alas and raci" mean to eat}

The verbs "alas and raci" are clearly different from the other related verbs.Those verbs designate the meaning of eating food or meals for breakfast. Both verbs have specific features showing the activity of eating food or meals only in the morning where people usually have breakfast. The given instances illustrate the meaning of those verbs as follows:

a. Neka hemong alas po pung gori.

b. Hi John raci kut ngo kerja one kantor.

c. Ami alas cama-cama agu meka.

d. Hi ema agu ende poli raci bao ga.

From the data, it is clear that the verbs "alas and raci" denote the notion of eating food or meals served on breakfast. The tools are spoons and plates, while the parts of body involved are hands and mouth.

\section{The Explication of the Meaning}

The meaning of the verbs "alas and raci" can be explicated as follows :

- X does something to $\mathrm{Y}$

- This happens on breakfast time.

- Y can be food or meals
- Because of this, X eats and chews food or meals in the mouth.

- $\mathrm{X}$ does something like this.

The doers $(\mathrm{X})$ can be any human subjects who engage in the eating activity on breakfast. Food or meals (Y) as the object are not directly mentioned. However, they can be found from the context. Both verbs cannot be used to indicate the notion of eating in other times (lunch, dinner).

\section{CONCLUSION}

As other local languages, Manggaraian language has an inventory of verbs signifying the notion of eating. The notion is reflected in certain lexicons such as "hang, lompong,jumik, alas,raci,pongo mu'u, mboros, takung". Based on the analysis of Natural Semantic Metalanguage, the verbs, regardless of the same basic meaning, show different semantic features. The verbs hang, jumik, mboros have a generic feature of meaning. The verbs lompong, pungo mu"u, alas, raci, takung, however, designates specific feature of meaning. In terms of semantic prime, all the verbs meaning to eat are categorized into the action verbs. The action verbs are non-compositional polysemy. However, the verbs jumik, lompong, pongo $m u^{\prime} u$ have more delicate meaning than the other verbs. Further, with respect to the explication of meaning, all the verbs desccribe the action and the process of eating involving certain parts of body like hands and mouth as well as the tools such as plate, spoon, bowl.The verbs are used with different subjects (doers).

In addition to the concluding points, the analysis found that the verb "hang" has the metaphorical extension of meaning. Metaphorically, the verb connotes the meaning of corruption and killing.

\section{REFERENCES}

Allan, K. (1986). Linguistic Meaning. Routledge.

Allan, K. (2016). A history of semantic. In Riemer, $\mathrm{N}$. The routledge handbook of semantics. In The Routledge Handbook of Semantics (First edit). Tylor \& Francis Group.

Cavanagh, R. F., Asano-Cavanagh, Y., \& Fisher, W. P. (2019). Natural Semantic Metalanguage as an approach to measuring meaning. Journal of Physics: Conference Series, 1379(1).

Fromkin, Victoria, Rodman, Robert \& Hyams, N. (2011). An Introduction to Language (9th ed.). WADSWORTH CENGAGE Learning.

Gladkova, A., Vanhatalo, U., \& Goddard, C. (2016). The semantics of interjections: An 
experimental study with natural semantic metalanguage. Applied Psycholinguistics, 37(4), 841-865.

Goddard, C. (2012). The Natural Semantic Metalanguage Approach. In The Oxford Handbook of Linguistic Analysis.

Griffths, P. (2006). Introduction to English Semantics and Pragmatics (H. Giegerich (ed.)). Edinburgh University Press.

Jama, K. B., Ardika, I. W., Ardhana, I. K., Setiawan, I. K., \& Menggo, S. (2020). Metaphor construction in caci performance of Manggarai speech community. Journal of Language Teaching and Research, 11(3), 418-426.

Jensen, D. F. N. (2006). Metaphors as a bridge to understanding educational and social contexts. International Journal of Qualitative Methods, 5(1), 1-17.

Menggo, S. (2017). Budaya lonto léok dalam kemampuan berbicara bahasa Inggris. The 1st International Conference on Language, Literature and Teaching, 764-772.

Menggo, S., \& Suastra, I. . M. (2020). Language use and language attitudes of Sumbawanese speakers in Bali. Register Journal, 13(2), 333350.

Menggo, S., Suastra, I. M., Budiarsa, M., \& Padmadewi, N. N. (2019). Speaking for academic purposes course: An analysis of language functions. E-Journal of Linguistics, 13(2), 314-332.

Mulyadi, M., \& Siregar, R. K. (2006). Kajian makna dalam linguistik. Jurnal Ilmiah Bahasa Dan Sastra, 2(2), 69-75.

Nasution, L. Y., \& Mulyadi, M. (2020). Market names in Medan: A natural semantic metalanguage study. RETORIKA: Jurnal Bahasa, Sastra, Dan Pengajarannya, 13(2), 235-245.

Rannas, K. S., \& Rosa, R. N. (2020). A semantic analysis of Minangkabaunese verbs connected to the semantic primes touch: A natural semantic metalanguage study. E-Journal of English Language \& Literature, 9(3), 1-8.

Sari, R. P., Kardana, I. N., \& Budiarta, I. W. (2021). Phonemes $/ \mathrm{mb} /$ and $/ \mathrm{kh} /$ on the Syllable Pattern of KV of South Nias Language. The 1st International Student Conference on Linguistic, 1(1).

Sarwadi. (2016). Predicate of Mangan in Sasak Language: A Study of Natural Semantic Metalanguage. Journal of Language and Culture, 2.

Setiawan,Inten Purnama Sari Luh Gede, L. Sutjiati Beratha, N. W. S. (2019). Meaning of Phrasal Verb 'Pick up' Subtype Do/Happen: A Natural Semantic Metalanguage Approach. EJournal of Linguistics, 13(2), 347.

Wearing, C. (2009). Metaphor and the Natural
Semantic Metalanguage. Journal of Pragmatics, 41(5), 1017-1028. 